\title{
Rhetorical Devices in English Advertisement Texts in India: A Descriptive Study
}

\author{
Barnali Chetia
}

\begin{abstract}
Rhetorical devices serve as a tool to lend beauty, variety, vividness, force, andpower to the language. Rhetoric plays a very important role in English advertisement, acting as a key element for the success of an advertisement. Advertising as we know is a form of communication intended to persuade an audience (viewers, readers or listeners) to purchase or take/ refrain from taking some action upon products, ideas, or services. It includes the name of a product or service and how that product or service could benefit the consumer and it aims to persuade a target market to purchase or to consume that particular brand or product. The present paper attempts a study of the rhetorical devices like simile, metaphor and personification found in English language advertisements in India.
\end{abstract}

Index Terms-Advertisements, communication, language, persuasion, rhetorical devices.

\section{INTRODUCTION}

Recent development in the sphere of advertising is the trend of interactive and 'embedded' ads, which are done via product placement, having consumers vote through text messages and utilizing social networking services such as Facebook etc. It is seen that modernadvertising developed with the rise of mass production in the late 19th and early 20th centuries. Different types of media are used to deliver these messages, including traditional media such as newspapers, magazines, television, radio, outdoor/ direct mail; or new media such as Websites and text messages. The advertising messages are usually paid for by sponsors and viewed via various media. An advertisement can be defined as a vital marketing tool as well as a powerful communication force.

\section{Rhetorical Devices}

The word rhetoric has been derived from Latin rhetoricaor rhetorice, which has originally come from Greek rhetorike meaning the technical art of rhetor, an orator or public speaker. Aristotle, in his first book Rhetoric (322-320 B.C), has defined rhetorical discourse as the art of discovering all the available means of persuasion in any given case [1]. Rhetorical devices serve as a tool to lend beauty, variety, vividness, force, and power to the language. Rhetoric plays a very important role in English advertisement, acting as a key element for the success of an advertisement. To achieve vividness and humor and to appeal to more readers, various

Manuscript received June 19, 2014; revised August 21, 2014.

Barnali Chetia is with the Heritage Institute of Technology, Kolkata, West Bengal, India (e-mail: bchetia03@gmail.com). rhetorical devices are employed in advertising. It can be said that the success of English advertisements has much to do with the apt employment of rhetorical devices. Some of the most commonly used rhetorical devices are discussed in the following analysis:

\section{A. Simile}

Simile is a comparison between two different things that resemble each other in at least one way. In formal prose the simile is a device both of art and explanation, comparing an unfamiliar thing to some familiar thing (an object, event, process, etc.).

A simile is a figure of speech that directly compares two things through some connective, usually "like," "as," "than," or a verb such as "resembles". A simile differs from a metaphor in that the latter compares two unlike things by saying that the one thing is the other thing.

\section{B. Using "Like"}

A simile can explicitly provide the basis of a comparison or leave this basis implicit. In the implicit case the simile leaves the audience to determine for themselves which features of the target are being predicated. It may be a type of sentence that uses "as" or "like" to connect the words being compared.

'...............For hope grew round me, like the twining vine.' (Coleridge -'Dejection-an ode') [2].

C. Using "As"

The use of "as" makes the simile more explicit.

- Cute as a kitten.

- As busy as a bee.

- As snug as a bug in a rug.

D. Without "Like" or "As"

Sometimes similes are submerged, used without using comparative words ("Like" or "As").

- 'Shall I compare thee to a summer's day? / Thou art more lovely and more temperate' William Shakespeare, Sonnet 18 [3], [4].

In the advertising world, a simile is an excellent way to communicate symbolic ideas. The advertising taglines witness a comparison between two distinctly different things by the usage of such words as, like, as-so, as if, etc. Copywriters have used this device very generously.

\section{E. Data (Examples)}

- Product: Kingfisher Airlines

Tagline: Few things connect India like Kingfisher does.

- Product: Veet (beauty product)

Tagline: What beauty feels like.

- Product: Chevrolet Cruze 
Tagline: Test it like you own it.

- Product: Thai Airways (service) Tagline: Smooth as silk.

- Product: McDonald

Tagline: Nobody can do it like McDonald's can.

- Product: Kiwi shoe polish

Tagline: When your shoesshine, so do you.

- Product: Guinness Advertising

Tagline: I feel like a Guinness -Iwish you were.

\section{F. Personification}

Personification is a figure of speech in which either an inanimate object or an abstract idea is represented as a person. By this figure of speech a thing, quality, or idea is spoken of as though it is endowed with human attributes or feelings. The usage of personification in English advertisement seems to give products emotion and liveliness. And also it caters to more trust and affection in potential customers and therefore arouses more desire for the purchase.

\section{G. Data (Examples)}

- Product: Listerine

Tagline: Always a bridesmaid, but never a bride.

In this ad, the product Listerine is said to a bridesmaid but never a bride, which means though Listerine is an inanimate thing, it is endowed with all human attributes or feelings as soon as it is compared to a bridesmaid.

\section{- Product: ESSO}

Tagline: Happiness is a quick-starting car.

In this advertisement, the car ESSO is personified as it is compared to the human feeling of happiness. ESSO here stands synonymous to happiness.

- Product: HONDA

Tagline: The power of dreams.

In this advertisement the product HONDA is personified as it stands synonymous to dreams and dreams are strictly associated to humans.

\section{- Product: CITIGROUP or CITIBANK}

Tagline: The citi never sleeps.

In this ad, CITIGROUP is personified as it is associated with sleeping. Sleeping is a human act and as the copy writer is saying that CITIGROUP never sleeps, it is giving the inanimate citi a human attribute (actually trying to say that CITIGROUP would be vigilant, and by never sleeping it would be at the service of its customers).

- Product: LEE

Tagline: The jeans that built America

-In this ad, "the jeans that built America," the inanimate object "jeans" is equated to a human abstraction who/which has the capability of building a country (an identity that is synonymous to America).

- Product: Fiat Punto

Tagline: The little carefree car.

In this ad, the car Fiat Punto is said to be a "carefree" car. The meaning of "carefree" in English is "free from care or anxiety.' And carefree is a human attitude wherein a person is without any kind of worry or fear. So by calling it a carefree car, this inanimate object is represented as a person. Thus, Fiat Punto is personified.

\section{H. Metaphor}

The word metaphor comes from the Greek word'metaphora', which means carrying a word or term over or beyond. Metaphor contains an implied comparison in which a word or phrase that is ordinarily or primarily used of one thing is transferred to another without giving a formal acknowledgement that any comparison is made. Aristotle (322-320 B.C) says in his Rhetoric that it is metaphor above all else that gives clearness, charm, and distinction to the style [5]. Metaphor not only explains by making the abstract or unknown concrete and familiar, but it also gives the reader (consumer) scope of imagination. The use of metaphors in advertising is a common way for copy writers to communicate a point to the consumer. Advertisers frequently use metaphors with words or visually with pictures. In the business of advertising, it is important to be accurate with any statement so that a message is not misconstrued. As a result, when there are metaphors in advertising, the copywriters often tread creatively around the truth. One way to do this is to use phrases with nouns only instead of full sentences when incorporatingmetaphors into a message. The use of metaphors in advertising is likely to evoke some type of emotion out of an audience and make the message memorable, which is the outcome in a successful ad campaign.

\section{Data (Examples)}

- Product: Glenlivet Wine

Tagline: The Glenlivet, the father of all Scotch.

- Product: Tropicana fruit juice

Tagline: Your daily ray of sunshine.

- Product: VimalSarees

Tagline: A woman expresses herself in many languages, Vimal is one of them.

- Product: Montblanc

Tagline: Montblanc Nobleless -- an eloquent expression of your personality and individual lifestyle.

- Product: Old Spice

Tagline: The mark of a man.

- Product: Raymond

Tagline: The complete man.

Thus, we have seen in the above-mentioned data that metaphor is a figure of speech that uses words (in the form of an image, story, or a tangible object) to represent a less tangible thing or some intangible quality or idea. The main aim of advertising is to hold potential buyer's attention and to influence his beliefs. And this is easily achieved by using metaphor. The metaphorical sense in advertising is achieved not only by text, but also by visual elements, sound, and context. Even advertisements that do not have metaphor in any of its elements can be metaphorical. Usage of polysemantic words helps to create complex metaphorical image, which appeals to human's emotional experience and subconscious. Thus the copywriters through their advertisement sell not only the product, but also abstract concepts like beauty, masculinity, femininity, attractiveness, happiness, and freedom. Moreover copywriters create a metaphor to represent a characteristic of a brand, a feature of the service, or a benefit of the product. A metaphor can be used to characterize the brand's personality. For example, a 
branding campaign for an investment bank uses the visual metaphor of a fencer, to characterize the company as aggressive yet sophisticated. Copywriters also use metaphor to represent a product feature, which is benefitting to consumers. Like in the ad for an iron enriched breakfast cereal showing a magnet attracting the cereal out of the bowl.

\section{J. Hypophora}

Hypophora, also referred to as anthypophora or antipophora, is a figure of speech in which the speaker poses a question and then answers the question. In English advertisements this figure of speech plays an important role as this figure of speech, unlike rhetorical questions, poses a question and then answers it too satiating the consumers' desire of getting an answer. This feature is seen to be used by copywriters in order to make the taglines more believable or rather establishing a contact with their potential consumers by answering the queries.

\section{K. Data (Examples)}

- Product: Goodyear Tyres

Tagline: Should a woman have to worry about tyres? Goodyear says no!

- Product: Baidyanath Rhuma oil

Tagline: Joint pain? Arthritis?

Suffer no more ....

- Product: PCRA

Tagline: Want to gift your wife a Diamond Ring?

Become a carpooler.

- Product: Pears soap

Tagline: How do you spell soap?

Why P-E-A-R-S, ofcourse.

- Product: Chivas Regal

Tagline: Isn't that a lot for a bottle of Scotch?

Yes.

- Product: Toohey's beer

Tagline: How do you feel?

I feel like a Toohey's.

\section{Epizeuxis}

In rhetoric, an epizeuxis is the repetition of words in immediate succession, for vehemence or emphasis. Copy writers use this figure of speech in order to create an impact (or the emphasis of the product) on the consumers' mind.

\section{Data (Examples)}

- Product: Anacin pain reliever

Tagline: Fast, Fast, Fast relief.

- Product: Old Spice

Tagline: Smell like a man, man.

- Product: Trans World Airlines

Tagline: Up, Up and away with TWA.

- Product: Energizer batteries

Tagline: It keeps going, and going, and going . . .

- Product: Cadbury's Drinking chocolate

Tagline: Hot chocolate, drinking chocolate -- the late, late drink.

- Product: Alka Seltzer

Tagline: Plop, Plop, fizz, fizz, oh what a relief it is!

- Product: Nicorette

Tagline: Nicorette, Nicorette, you can beat the cigarette.
- Product: Tata Indicom

Tagline: Talk as you pay, pay as you talk.

\section{N. Hyperbole}

Hyperbole is a Greek word, which literally means "throwing beyond." As a figure of speech, hyperbole is a deliberate overstatement or extravagant exaggeration of fact used for producing a serious or comic effect. In advertising, the use of exaggerated statements or rather overstatements puts emphasis on the particular features of the products or services.

\section{O. Data (Examples)}

- Product: Samsung

Tagline: World's Best.

In this advertisement, the copywriter uses hyperbole to claim that their product is the best in the world. It shows the confidence and heroic spirit of this brand. And it also gives the consumers a very profound impression. However, the claim also sounds like an overstatement.

- Product: Lufthansa

Tagline: There's no better way to fly.

In this advertisement, the copywriters made an overstatement by saying that there's no better way to fly. In the process of claiming that their brand is the best, they have made an exaggeration as there are many other airlines, which are giving pretty good services. Thus, this tagline is a hyperbole.

- Product: V.I.P

Tagline: India's no.1 luggage

In this advertisement, the above-mentioned tagline is a hyperbole as the copywriter has not done any sample study before making this claim. On what basis have they said that the aforesaid product is no.1 in India? Thus it's an overstatement made by the copywriter.

- Product: Shanti Gears Limited

Tagline: A never-ending story of challenging successes!

In this advertisement, the copy writers' made a hyperbole by using the above mentioned tagline as where is their story (evidence) of challenging successes. It's a mere statement or rather overstatement without evidence.

- Product: Asian Paints

Tagline: Colour that stays Come what may.

The tagline of this advertisement is a hyperbole as it is not possible that colour would continue to stay even when there's some natural calamity like earthquakes or tsunami. So the claim made by the copywriter is an overstatement or an exaggeration.

\section{P. Parallelism}

Generally, repetition of words and expressions is regarded as a sign of bad style. But still it is commonly used, either in form of total equivalence or paraphrastic substitution, meaning a different pattern of recurrence where something is repeated in other words.

Parallelism is a figure of repetition, which is of interest to rhetoric as well as literature. The term stands for the repetition of linguistic patterns such as sentences, phrases, and expressions. Parallelism, with its unexpected regularity, is also considered to be a main type of foregrounding. It is a 
form of repetition, either of sound or pattern, which constitutes an effective technique of memorizing particular statements, a method that is especially valuable in advertising It is particularly useful since the commercials' primary aim is the persuasion of the consumer, which can be most easily achieved when a slogan is repeated and hence memorized by the consumer. Along with that it also serves as a means of cohesion by maintaining coherence in the advertising texts.

Today advertisements are understood as any type or form of public announcement intended to promote the sale of specific commodities or services. They are predominately used for commercial purpose; especially for the so-called consumer advertising where the intention of the advertisement is the marketing of a certain product. Commercials and advertisements function by means of persuasion -- the messages are designed in a manner that influences the way the consumer perceives goods.

Again parallelism can also be explained as a succession of two or more syntactic identical constructions that are connected with or without a conjunction.

\section{Q. Data (Examples)}

- Product: Seven-up

Tagline: Fresh up with seven-up.

- Product: Energizer Batteries

Tagline: He keeps going and going and going.

- Product: Sony Playstation

Tagline: Live in your World, play in ours.

- Product: Nintendo 6

Tagline: Get $\mathrm{N}$ or get out.

- Product: Pringles

Tagline: Once you pop, you can't stop.

- Product: Memorex

Tagline: Is it live, or is it Memorex?

\section{R. Pun}

This figure of speech play upon words that is similar in sound but different in meaning. In the most general of terms, a pun is a form of speech play in which a word or phrase unexpectedly and simultaneously combines two unrelated meanings. Pun is one of the most common forms of word play and one of the figures of speech most often used in advertising. Puns may be used in three different ways:

1) By using a word equivocally.

2) By using a word more than once in different senses.

3) By using words similar in sound but different in meaning.

\section{S. Data (Examples)}

- Product: Coke

Tagline: Coke refreshes you like no other can.

"Can" in English has two meanings. One is to be able to do something. The other is a closed metal container in which foods or drinks are preserved and sold. The two different meanings of "can" give rise to two different interpretations of this advertisement:

Coke refreshes you like no other drinks can do.

Coke refreshes you like no other can-packed drinks can do.

- Product: Capri Cigarettes

Tagline: She's gone to Capri and she's not coming back.

In this ad the homonymic pun is based on the similarity between a place called Capri (an island in Italy) and the brand of cigarettes called Capri and this presents a false homology (homology is any similarity or correspondence that involves an element that is forced to bear double meaning), and this homology is considered "false" as it presents the reader with an incongruity. One interpretation that can be extracted from this ad is thata woman has left her present abode to live in a place called "Capri" and because she likes where she lives now, she has no plans of returning to where she lived before. Another interpretation of the ad is that a woman has changed her cigarette brand to "Capri", and because of her satisfaction with this new brand she has no intention of smoking her old brand again. And the interpretation, which the copywriters would like one to follow is that Capri is a much more preferable brand of cigarette than the current brand of the viewer, and once the viewer smoke it he will realize this and change.

- Product: Batiste Shampoo

Tagline: Give your hair a touch of spring.

"Spring" as we know has got three meanings: first of all it can be a body of rushing water; second, it means elasticity; and third, it's the spring season, which stands for youth, freshness, vivacity, life etc. This advertising tagline wants to promise the consumers that the product can keep their hair moist, elastic (bouncy), and the usage of this shampoo will make their hair full of life keeping it active and healthy.

- Product: More (cigarette)

Tagline: Ask for More

In this advertisement the copywriter is playing with the word "more." This word "more" can stand for absolute comparison and relative comparison. In both the cases, the copywriter has successfully brought out the motive behind the tagline. First of all, as the brand name is "more", a consumer is asked to ask for the brand. And second, a consumer is asked to ask for more of the "more" brand.

- Product: Neutrogena Body Oil

Tagline: Wear something silky after the shower

In the ad tagline the verbal text is represented by a pun in which the word "silky" communicates two meanings. First of all, the ad directly suggests one to use Neutrogena Body Oil after a shower as it makes the skin feel soft and silky and this could be said to be the literal meaning of the advertisement. However, the additional meaning linked to the word "silky" is suggestive of a romantic encounter in which a woman might slip into a negligee after a shower. Thus the copywriter leaves behind enough scope for the consumers to assess the merits of the product mainly by highlighting the point that by using Neutrogena Body Oil, their bodies will feel smooth, soft, silky, and sensual.

- Product: Impulse Body Spray

Tagline: Are you ready to feel this fresh?

(the image with the ad shows a woman eating a lemon)

This pun in this ad rests on the double meaning of the word "fresh" and in this example it is both verbal and visual. From the image of the woman eating a lemon, the reader will link this to the word "fresh" to find meaning and then try to understand it in terms of how the word is being used to describe the freshness of the lemon in relation to how it tastes and possibly how it feels. In relation to the body spray, the word "fresh" is being used to express how you will feel after 
using the product and as such "fresh" equates to being cool and feeling invigorated. Although the homology between the lemon and body spray is, strictly speaking false, its usages invites the consumer to find a link between the two and in doing so, to resolve the incongruity.

- Product: Farley's Baby Milk

Tagline: In 1906 men started pleasing women at night.

(The image shows a man holding a baby whilst pouring some milk in the baby's mouth with his wife in the background sleeping)

The word "pleasing" here takes on a double meaning as on one level, it relates to how the man's wife must feel now that he has taken on the role of care and therefore wakes up in the middle of the night to feed the baby whilst she sleeps. This is a clear reversal of roles given the time and as such, the woman is "pleased" with her husband for taking on this extra responsibility. On another level, the tagline introduces a double entendre with the slight implication of a sexual connotation based on the idea that the man can also be said to be "pleasing" his way wife by satisfying her in a sexual way. Given the visual image of the ad however, the reader is most likely inclined to reject the latter interpretation and stick with the former in order to find the real meaning of the advertisement.

- Product: Heaven Sent

Tagline: Heaven Sent. You don't have to be an angel to wear it.

In this advertisement "sent" is past participate of "send", "sent", and "scent" are homophones. "Sent" means "take", and "scent" is a kind of perfume, so we can understand the meaning of this advertisement -- an "angel" is "heaven sent" and heaven is associated with all the goodness; and the tagline says that the product is good and is well within reach of the common consumer as one doesn't have to be necessarily from the heaven to wear it (as we presume that angels live in heaven).

\section{CONCLUSION}

Rhetoric is not simply a matter of how thoughts are presented but is itself an influence on ways of thinking, which deserves serious attention. Attending to rhetorical devices can assist us in deconstructing almost all kinds of discourse, especially advertising language. Rhetorical devices such as metaphor, simile, personification, etc. are frequently used consciously in advertising.

\section{ACKNOWLEDGEMENT}

I would like to convey my heartfelt thanks to the cooperative and genial staff of the JNU library and the NCERT library, New Delhi, India.

\section{REFERENCES}

[1] G. Kennedy, Classical Rhetoric and Its Christian and Secular Tradition from Ancient to Modern Times, Chapel Hill: University of North Carolina Press, 1980, pp. 25-26.

[2] R. Ashton, The Life of Samuel Taylor Coleridge, Oxford: Blackwell, 1997, pp. 201-203.

[3] J. Schiffer, Shakespeare's Sonnets, New York: Garland Pub, 1999, pp. 124.

[4] P. Simpson, Stylistics, New York: Routledge, 2004, pp. 27.

[5] S. R. Levin, "Aristotle's theory of metaphor," in Philosophy and Rhetoric, vol. 15, pp. 24-46, 1982.

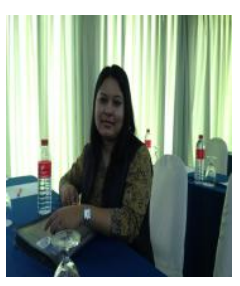

Barnali Chetia is an assistant professor, in Humanities Department, Heritage Institute of Technology. Kolkata, India.

I was born in the year 1983 in Assam, India. I have worked as a copy editor in Macmillan Publishing Solutions, New Delhi, 2008-2009. I was a visiting faculty English in Global School of Management Sciences, New Delhi, India, 2010. I have also worked as an assistant professor in English language and technical communication, Om Dayal College of Engineering and Architecture, Howrah, West Bengal, India, 2010-2011. I have done my M. A and M. Phil in Linguistics from JNU, New Delhi, India. Since 2011, I have devoted all my time to my Ph.D. research and I was awarded the Ph.D. degree at JNU, New Delhi in June 2014. Currently I am working as an assistant professor at Heritage Institute of Technology, Kolkata, India. My research interests are applied linguistics, sociolinguistics and discourse analysis. 